Zeszyty Naukowe Szkoły Głównej Gospodarstwa Wiejskiego w Warszawie Problemy Rolnictwa Światowego tom 17 (XXXII), zeszyt 2, 2017: 155-165

DOI: $10.22630 /$ PRS.2017.17.2.35

Joanna Nowakowska-Grunt $^{1}$, Barbara Kiełbasa ${ }^{2}$

${ }^{1}$ Politechnika Częstochowska

${ }^{2}$ Uniwersytet Rolniczy w Krakowie

\title{
Możliwości usprawniania procesów zarządzania w łańcuchu żywnościowym na przykładzie Produktu Lokalnego z Małopolski ${ }^{3}$
}

\section{Possibilities of Improving Management Processes in the Food Chain on the Example of the Local Product from Małopolska}

\begin{abstract}
Synopsis. Celem artykułu była analiza i ocena znaczenia krótkich łańcuchów dostaw w kontekście minimalizowania niekorzystnych zjawisk występujących w klasycznych łańcuchach dostaw. W pracy przedstawiono studium przypadku Produkt Lokalny z Małopolski, jako przykład dobrych praktyk. Analizując koncepcję skróconych łańcuchów dostaw można zauważyć istotne korzyści dla producentów rolnych, dla konsumentów, a także dla regionu. Ograniczenie ogniw łańcucha żywnościowego przynosi więcej korzyści rolnikowi, a dzięki skróceniu łańcucha do minimum można uniknąć reperkusji efektu Forrestera. Krótkie łańcuchy żywnościowe można zastosować do promocji regionu, produkcji ekologicznej, czy też produktów lokalnych i tradycyjnych. Mimo słabych stron jakim jest lokalny wymiar omawianej koncepcji, idea ta przyczynia się do realizacji założeń rozwoju zrównoważonego, która łączy cele ekonomiczne, z celami społecznymi i ochroną środowiska. Przedstawione rozważania nie wyczerpują tematu, a jedynie sygnalizują zagadnienie, które wymaga całościowego podejścia do tej tematyki.
\end{abstract}

Słowa kluczowe: łańcuch żywnościowy, zarządzanie, zagrożenia, korzyści, produkt lokalny

\begin{abstract}
The main goal of the article was to discuss the importance of introducing short supply chains in the context of minimizing the adverse effects of traditional supply chains. The paper presents a case study of the Local Product of Malopolska as an example of good practice. When analyzing the concept of shortened supply chains, some significant benefits for agricultural producers, consumers and the region can be noticed. Reduction of the food chain links brings more benefits to farmers, and can contribute to avoiding the Forrester's effect repercussions. Short food chains can be used to promote a region, as well as organic, local or traditional products. Despite the weaknesses of the local dimension of this concept, the idea contributes to sustainable development, which links economic goals, with social and environmental objectives. Presented reflections do not exhaust the subject, but only signal a topic that requires a holistic approach to the subject.
\end{abstract}

Key words: food chain, management, constraints, benefits, local product

\section{Wprowadzenie}

Wejście Polski do Unii Europejskiej wywołało liczne konsekwencje na polskim rynku żywnościowym. Jedną $\mathrm{z}$ nich był wzrost konkurencji i narastanie rywalizacji pomiędzy dostawcami produktów żywnościowych. Z drugiej strony pojawiły się możliwości wsparcia

\footnotetext{
${ }^{1}$ dr hab., prof. PCz, Wydział Zarządzania, Politechnika Częstochowska, e-mail: jnowakowskagrunt@onet.eu 2 dr, Zakład Polityki Społecznej i Doradztwa, Uniwersytet Rolniczy w Krakowie, Al. Mickiewicza 21, 31-120 Kraków, e-mail: bkielbasa@ar.krakow.pl

${ }^{3}$ Publikacja została sfinansowana z dotacji celowej na naukę przyznanej przez Ministerstwo Nauki i Szkolnictwa Wyższego.
} 


\section{J. Nowakowska-Grunt, B. Kiełbasa}

finansowego w zakresie zapewniania bezpieczeństwa żywnościowego, i na ten cel przeznaczane są znaczne środki wsparcia finansowego (Prus, 2008).

W tej sytuacji coraz powszechniejsze jest przekonanie, że skuteczne i efektywne konkurowanie w sektorze agrobiznesu wymaga dysponowania określoną wiedzą i umiejętnościami, niezbędnymi $\mathrm{w}$ procesie podejmowania decyzji, zwłaszcza z zakresu zarządzania łańcuchem dostaw żywności. Agrobiznes jest specyficznym działem gospodarki narodowej (Małysz, 1998). E. Pudełkiewicz (2011) wymienia wiele aspektów wyróżniających ten sektor. Są to m.in. specyfika przedsiębiorstw, które działają na rynku środków do produkcji, specyfika podaży i popytu na produkty rolno-spożywcze, specyfika gospodarstw rolnych - jako podmiotów działających na rynku rolnym. K. Firlej (2008) wskazuje, iż istotne są także takie czynniki, jak koszty magazynowania i transportu żywności, brak koncentracji produkcji rolnej (duża liczba małych producentów rolnych), a także specyfika produktów rolniczych (mogą ulec zepsuciu i zniszczeniu na każdym etapie procesu produkcyjnego). Uwarunkowania te wpływają na konieczność poszukiwania i wprowadzania nowych rozwiązań, które przyczynią się do usprawnienia procesów zarządzania łańcuchem żywnościowym, a tym samym do minimalizowania słabych stron niektórych ogniw łańcucha i zapewnienia bezpieczeństwa żywnościowego. Wciąż poszukiwane są rozwiązania, które pozwolą na zwiększenie sprawności funkcjonowania ogniw i podniesienie poziomu konkurencyjności producentów żywności. Współcześnie rosnąca konkurencja na rynku żywnościowym oraz wymagania konsumentów sprawiają, iż konieczne są nowe, innowacyjne rozwiązania, niejednokrotnie wymagające poniesienia dużych kosztów, a także współpracy wielu podmiotów, w tym także doradztwa rolniczego i nauki. Tworzone są liczne koncepcje innowacyjnych rozwiązań na rynku żywnościowym, które uwzględniają procesy produkcji, przetwórstwa i logistyki ${ }^{4}$.

Zaprezentowane w artykule wybrane koncepcje zarządzania łańcuchami dostaw, to istotne zagadnienia podejmowane $\mathrm{w}$ badaniach $\mathrm{i}$ literaturze. W niniejszym opracowaniu skupiono się na wybranych rozwiązaniach $\mathrm{w}$ zakresie zarządzania łańcuchem dostaw żywności, których ideą jest promowanie rozwoju zrównoważonego, zmniejszenie kosztów dystrybucji oraz wykorzystanie potencjału małych gospodarstw rolnych. Przedstawione w pracy studium przypadku prezentuje potencjał drobnych gospodarstw rolnych, które nie mają szans konkurować z innymi uczestnikami łańcucha żywnościowego, stąd też muszą poszukiwać nowych rozwiązań. Prezentowany przykład pokazuje w jaki sposób można dokonać wzmocnienia najsłabszych ogniw łańcucha oraz zniwelować zagrożenia wynikające z działań innych uczestników, dzięki skróceniu łańcucha do minimum.

\section{Dane i metody}

Celem opracowania jest analiza i ocena łańcucha żywnościowego z uwzględnieniem koncepcji skracania łańcucha dostaw - na przykładzie Produktu Lokalnego z Małopolski. Wykorzystano metodę studium przypadku w oparciu o analizę przykładu dobrych praktyk, który może posłużyć jako benchmark w procesach zarządzania łańcuchem żywnościowym dla drobnych gospodarstw rolnych. W pracy dokonano analizy wybranych metod zarządzania procesami w łańcuchu żywnościowym, których celem jest podniesienie

\footnotetext{
${ }^{4} \mathrm{~Np}$. model innowacji produktowych i procesowych w produkcji trzody chlewnej i przetwórstwie mięsa wieprzowego opracowany przez W. Knapik (Knapik, 2016).
} 
poziomu konkurencyjności drobnych gospodarstw rolnych. Przedstawiono analizę znaczenia krótkich łańcuchów dostaw w kontekście efektu Forrestera, który pojawia się w tradycyjnych łańcuchach dostaw. Przeprowadzono analizę literatury naukowej w zakresie łańcucha żywnościowego i zarządzania logistycznego w agrobiznesie. Metodami badawczymi były: studium przypadku oraz metoda dedukcyjno-indukcyjna.

\section{Przegląd literatury}

Kwerenda literatury $\mathrm{w}$ zakresie zarządzania procesami w łańcuchu żywnościowym wskazuje na istotne znaczenie tego zagadnienia we współczesnej gospodarce. A. Czyżewski (2001) podkreśla, iż ogniwa występujące w łańcuchu żywnościowym istotnie implikują poziom życia obywateli, wpływają na ich sytuację społeczno-ekonomiczną, a także świadomość ekologiczną. Wielu badaczy tego zagadnienia wskazuje, iż łańcuch żywnościowy można analizować i intepretować nie tylko w kontekście relacji ekonomicznych, ale także społecznych i przyrodniczych, które wzajemnie na siebie oddziałują i decydują o skuteczności łańcucha żywnościowego (Jarzębowski, Klepacki, 2012). Knapik (2016) podkreśla, iż istotne jest ,zrównoważenie pod względem ekonomicznym $i$ spolecznym, a także środowiskowym $w$ produkcji $i$ przetwórstwie żywnośc $i$ ", i te trzy obszary nie powinny być analizowane odrębnie.

W klasycznym ujęciu łańcuch żywnościowy definiuje się jako zbiór pewnych procesów, związanych z żywnością i jej składnikami (Małysz, 1998). Natomiast współcześnie za łańcuch żywnościowy często przyjmuje się zintegrowaną strukturę, w której łączy się wiele elementów, począwszy od producentów rolnych, aż do konsumentów żywności (Gołębiewski, 2010). Pomiędzy ogniwami w łańcuchu żywnościowym występują różne powiązania. Poszczególne ogniwa tworzą tzw. łańcuch, na który składają się sekwencje różnorodnych procesów. Można je podzielić na (Juchniewicz, 2015; Witkowski, 2010):

- podstawowe: zwiazane $\mathrm{z}$ wytwarzaniem produktów podstawowych $\mathrm{i}$ ich przetwarzaniem,

- pomocnicze: wspomagające procesy produkcji i przetwarzania,

- zarządzania: służą do określania celów i strategii,

- zakupu: sprzedaż odpowiednich ilości surowców, półproduktów i produktów żywnościowych oraz nieżywnościowych służących do produkcji,

- związane z konsumentami i innymi klientami: budowanie relacji z odbiorcami,

- kontroli: kontrolowanie jakości wszystkich procesów w łańcuchu,

- logistyczne: związane z przepływami produktów i materiałów w całym łańcuchu,

- zarządzania wiedzą i informacją: niezbędne do realizacji wszystkich procesów w łańcuchu żywnościowym.

E. Pudełkiewicz (2011) podkreśla szczególne znaczenie dwóch procesów: logistycznych oraz procesów zarządzania informacją. Według tej Autorki, są one niezbędne do realizacji wszystkich procesów w łańcuchu żywnościowym i wspomagają zarządzanie całym łańcuchem. Istotne znaczenie przypisuje się procesom logistycznym, które generują znaczące koszty, a w łańcuchu żywnościowym określa się ja mianem agrologistyka (Klepacki, 2011). Według B. Klepackiego (2016) agrologistykę można zdefiniować jako „działalność zwiqzanq z realizacja funkcji zarzqdzania $w$ procesie przepływu towarów 
rolno-spożywczych od miejsca wytworzenia, poprzez kanaty zwiqzane z ich dystrybucja i magazynowaniem, aż do konsumenta finalnego". Efektem skutecznego zarządzania procesami agrologistycznymi powinno być zapewnienie bezpieczeństwa żywnościowego, przy jednoczesnym osiaganiu korzyści ekonomicznych (Bezat-Jarzębowska, Jarzębowski, 2014). J. Gołębiewski (2007) dodaje, iż systemy logistyczne „tworza specyficzny układ funkcjonalnych $i$ instytucjonalnych zależności". Słuszne jest więc stwierdzenie, iż na realizację procesów logistycznych w łańcuchu żywnościowym duży wpływ mają czynniki o charakterze zewnętrznym, będące efektem działalności oraz współpracy różnych przedsiębiorstw przetwórczo-dystrybucyjnych oraz instytucji sektora agrobiznesu.

Obecnie w łańcuchu żywnościowym następują istotne zmiany, wynikające przede wszystkim z rosnącej konkurencji na rynkach lokalnych, regionalnych i globalnych. Jeśli chodzi o rolników i producentów rolnych, coraz większe wymagania rynku powodują, iż konieczne są różne procesy konsolidacji i współpracy (Nowakowska-Grunt, Parzonko, Kiełbasa, 2016; Kalinowski, Zielińska-Chmielewska, 2014). Jest to także efekt zmian w systemie agrobiznesu i agrologistyki, a także poszukiwania i wprowadzania innowacyjnych rozwiązań, które usprawniają procesy w łańcuchu żywnościowym i powoduja zmniejszenie kosztów. Według M. Parlińskiej (2015), podstawą rozwoju rolnictwa i samoorganizacji społecznych na wsi są rodzinne gospodarstwa rolne. Małe gospodarstwa stanowią podstawę polskiego rolnictwa. Mimo, iż borykają się z wieloma problemami i nie mogą konkurować na rynkach globalnych, posiadają wiele atutów, które można wykorzystać, zwłaszcza na arenie lokalnej i regionalnej. Producenci rolni i przetwórcy wciąż poszukują nowych metod, które wpłyną na poprawę efektywności produkcji oraz zwiększenie konkurencyjności na rynku żywnościowym. Jedną z koncepcji jest łańcuch żywnościowy promujący tzw. krótkie dostawy (Kneafasy i in., 2013). Łańcuch krótkich dostaw to koncepcja upowszechniana m.in. przez Europejskie partnerstwo innowacyjne na rzecz wydajnego i zrównoważonego rolnictwa, tzw. EPI-AGRI (The Agricultural European Innovation Partnership) (Grupa fokusowa EIPAGRI Innowacyjne Zarządzanie Krótkim Łańcuchem Dostaw Żywności, 2015).

\section{Ograniczenia procesów zarządzania w łańcuchu żywnościowym i sposoby ich usprawniania}

Skuteczne zarządzanie lańcuchem żywnościowym polega na zapewnieniu odpowiedniej jakości żywności na każdym etapie jej produkcji i przetwarzania. Żywność jest szczególnym produktem, na jakość którego ma wpływ wiele czynników wewnętrznych - zależnych od producenta, oraz tych zewnętrznych - na które przedsiębiorca (producent rolny lub przetwórca) ma niewielki wpływ (Szymanowski 2008). Jakość i konkurencyjność produktów żywnościowych zależą także od skuteczności zarządzania łańcuchem dostaw i realizacji procesów logistycznych.

Zarządzanie łańcuchem dostaw to złożony proces, który wymaga decyzji związanych z organizacją sieci partnerów, komunikacji między nimi, współpracy, poszukiwania narzędzi do skutecznego planowania, a także koordynacji przepływu towarów i pieniędzy (Ciesielski, 2009). Decyzje te można podzielić na cztery fazy: od strategicznych poprzez taktyczne i operacyjne, aż do analizy wydajności łańcucha dostaw. Należy do nich zaliczyć (Baran i in., 2008):

- projektowanie łańcucha dostaw: planowanie długoterminowe, 
- decyzje w początkowej fazie planowania: uwzględniają krótkoterminowe prognozy na rynku,

- realizacja zamówień: kontrolowanie przepływów materiałów w ramach sieci logistycznej z uwzględnieniem określonego horyzontu czasowego,

- monitorowanie łańcucha dostaw: wszystkie działania związane $\mathrm{z}$ analizą skuteczności poszczególnych elementów łańcucha dostaw.

W kontekście procesów logistycznych w łańcuchu żywnościowym, priorytetowym celem dla jego uczestników jest m.in. ograniczenie zapasów, zmniejszenie kosztów magazynowania, wprowadzenie małych ale częstych dostaw, bądź też zapewnienie odpowiedniej jakości dostaw. Istnieje wiele koncepcji, które pozwalają na usprawnienie procesów w łańcuchu logistycznym (Juchniewicz, Grzybowska, 2010). Wprowadzane innowacje usprawniają produkcję żywności i zapewniają odpowiednią jakość i terminowość dostaw, a także gwarantują skuteczność zarządzania na każdym etapie łańcucha żywnościowego (Tul-Krzyszczuk, Krajewski, 2014). Innowacyjne koncepcje powinny uwzględniać tzw. teorię ograniczeń (Theory of Constraints), która głosi, iż łańcuch jest tak silny, jak jego najsłabsze ogniwo (Hugos, 2003). Istotne jest także dążenie do unikania implikacji wynikających z tzw. efektu Forrestera (Lee, Padmanabhan, Whang, 2002). Efekt ten, nazywany także efektem motyla lub byczego bicza, polega na tym, iż małe zakłócenia warunków początkowych powodują znaczne zakłócenia działania całego systemu, poprzez sprzężenie zwrotne (rys. 1).

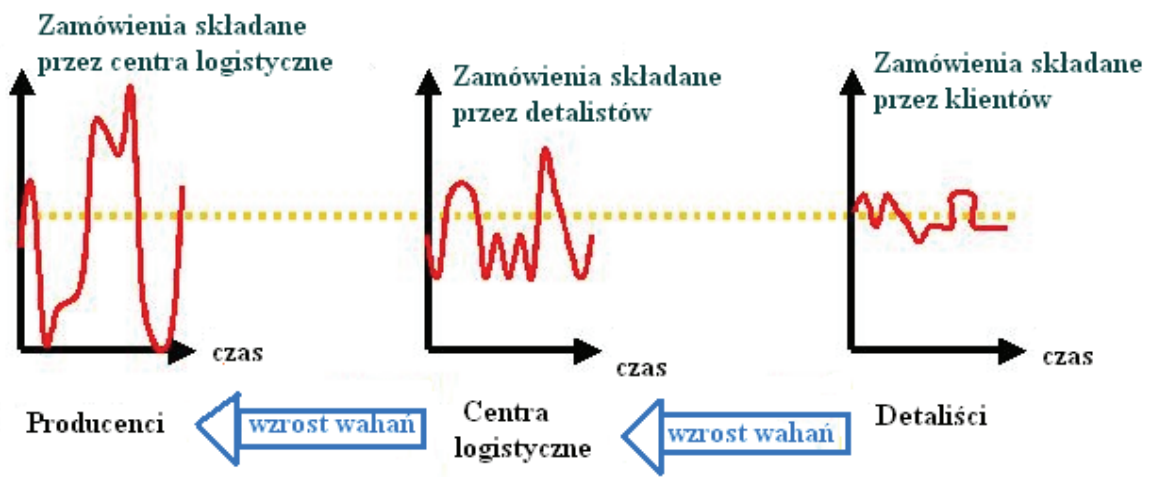

Rys. 1. Efekt Forrestera w tradycyjnym łańcuchu dostaw

Fig. 1. Forrester effect in the traditional supply chain

Źródło: Pluta-Zaremba, A. (2002). Efekt byczego bicza w łańcuchu dostaw. Gospodarka Materiałowa i Logistyka, s. 5 .

Zagrożenie wystapienia efektu motyla jest tym większe im więcej pośredników w łańcuchu dostaw i dłuższy czas realizacji dostaw. Efekt ten jest także wynikiem słabego przepływu informacji, manipulowania cenami lub grupowania zamówień (Van der Vorst, 2000). Jako uniwersalne działania, postulowane przy ograniczaniu tego niekorzystnego efektu, wymienia się przede wszystkim dzielenie się wiedzą i informacja, koordynację wszystkich procesów $\mathrm{w}$ łańcuchu dostaw i wspólne podejmowanie decyzji, a także zmniejszanie liczby pośredników i usprawnienie przepływów materiałowych w łańcuchu żywnościowym (Mayerson. 2007; Closs i in., 1998). 


\section{Przykład dobrych praktyk - Produkt Lokalny z Małopolski}

Żywność jest szczególnym dobrem, na jakość którego wpływa wiele czynników. Aby zmniejszyć wpływ negatywnych zjawisk, szczególnego znaczenia nabiera zastosowanie tzw. krótkich łańcuchów dostaw żywności.

Krótkie łańcuchy dostaw to forma współpracy producentów, dostawców i przetwórców żywności na poziomie lokalnym. Według definicji EPI-AGRI „krótki łańcuch żywności to takie zorganizowanie produkcji, dystrybucji i transakcji pomiędzy producentem żywności a kupujacym, aby zminimalizować liczbe pośredników uczestniczacych w tym procesie do minimum" (The Agricultural European Innovation Partnership, www.eipagri.eu). Liczba uczestników łańcucha żywnościowego będzie różna $\mathrm{w}$ zależności od typu produkowanych i sprzedawanych produktów ( $\mathrm{w}$ tej roli np. produkcja mięsa vs. uprawa zbóż, itd.). Krótki łańcuch funkcjonuje w oparciu o pośredników lokalnych lub tzw. animatorów (np. lokalne grupy działania) i wykorzystuje potencjał lokalnych producentów (Kozera, 2007). Najważniejszą korzyścią i ideą łańcucha krótkich dostaw jest wyeliminowanie pośredników (Kawecka, Gębarowski, 2015). Ponadto krótki łańcuch żywności zapewnia producentowi uzyskanie większych dochodów ze sprzedaży żywności, dzięki skróceniu łańcucha. Produkcja i dystrybucja żywności koncentruje się na rynkach lokalnych. Koncepcja ta stanowi element lokalnych systemów żywnościowych. Jest od lat promowana i implementowana $\mathrm{w}$ krajach Unii Europejskiej, jako jeden $\mathrm{z}$ elementów rozwoju zrównoważonego (Kneafsey i in., 2013, Canfora, 2016).

Produkt Lokalny z Małopolski (PLM), jako koncepcja krótkiego łańcucha dostaw żywności, powstał w 2011 roku w efekcie projektu realizowanego przez Fundacje Partnerstwo dla Środowiska. W projekcie uczestniczy obecnie około 160 rolników i małych producentów z Małopolski (http://produktlokalny.pl/). PLM to nie tylko idea przetwarzania i sprzedaży żywności w oparciu o zbliżenie producenta $\mathrm{z}$ konsumentem oraz wykorzystanie lokalnych produktów. Koncepcja PLM podkreśla także znaczenie tradycji i kultury, nie tylko tych kulinarnych. PLM stanowi przykład lokalnego systemu sprzedażowego. Celem PLM było utworzenie krótkiego łańcucha dostaw żywności, w którym wykorzystuje się przede wszystkim sprzedaż bezpośrednią. W ramach certyfikatu PLM producenci sprzedają m.in. warzywa, wędliny, soki jabłkowe, miody, ryby, wyroby mączne, chleb, itd. Lista produktów znajduje się na stronie internetowej Produktu Lokalnego z Małopolski (http://produktlokalny.pl/certyfikowani-producenci-zywnosci-z-malopolski/). Produkty te są ściśle związane $\mathrm{z}$ danym regionem, charakteryzują się unikatowymi recepturami lub posiadają wyjątkową historię związaną $\mathrm{z}$ ich powstaniem. Ich produkcja $\mathrm{w}$ specyficzny sposób integruje czynniki ekonomiczne (możliwość zwiększenia dochodów), ze społecznymi (ludzie $\mathrm{i}$ ich dziedzictwo) oraz środowiskowymi (ochrona przyrody i bioróżnorodności), wpisując się w koncepcję rozwoju zrównoważonego (Galli, Brunori, 2013).

PLM jest ściśle związany z regionem i wykorzystuje oraz wspiera marki lokalne. Stąd też procesy zarządzania dystrybucją i logistyką mają nieco inny charakter niż w innych branżach, szczególnie tych prosperujących w oparciu o szersze rynki (krajowe, międzynarodowe) (Local Food and Short Suppy Chains, 2017). Sprzedaż produktów w ramach systemu PLM odbywa się za pomocą kanałów, które odpowiadają na potrzeby lokalnych konsumentów, a także znajdują się w zasięgu możliwości drobnych producentów i przetwórców żywności. System ten wykorzystuje takie kanały dystrybucji jak: sklepy, lokalne targi, sprzedaż internetowa (platforma IT), sprzedaż u rolnika/producenta żywności, 
katering, sprzedaż okazjonalna, restauracje, centra sprzedaży czy klub zakupowy (http://produktlokalny.pl/). Ideą jest, aby każdy kanał funkcjonał na zasadzie ,,krótkiego tańcucha dostaw”, po to by wyeliminować liczbę pośredników do minimum (rys. 2).
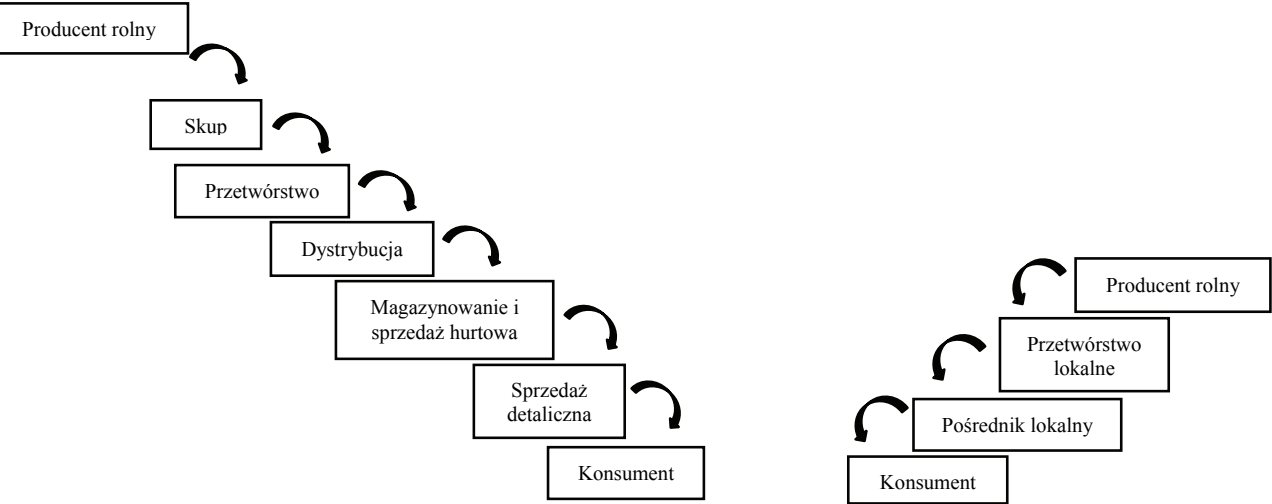

Rys. 2. Przykład tradycyjnego oraz krótkiego łańcucha dostaw żywności

Fig. 2. An example of traditional and short food supply chains

Źródło: opracowanie własne.

Na rysunku 2 przedstawiono schemat łańcucha żywnościowego w klasycznym ujęciu, oraz przykład krótkiego łańcucha dostaw żywności, wykorzystywanego przez PLM. W ramach systemu krótkich łańcuchów dostaw następuje integracja kanałów dystrybucji i zmniejszenie kosztów. Może także pojawić się efekt synergii, który wynika ze współpracy podmiotów działających w łańcuchu (wymiana wiedzy i informacji, wsparcie).

W procesie zarządzania PLM brane są pod uwagę trzy rodzaje wskaźników, które można wyszczególnić w zarządzaniu łańcuchem żywnościowym. Są to wskaźniki ekonomiczne, społeczne i środowiskowe. Wskaźniki ekonomiczne dotyczą liczby uczestników sieci współpracy, a także produktu i jego ilości. Wskaźniki społeczne odnoszą się do poziomu zaufania producentów rolnych, ich zaangażowania we wspólne projekty w ramach PLM, a także poza nim (rozwój lokalnych społeczności), oraz budowania świadomości konsumentów na temat zdrowej żywności i lokalnego patriotyzmu. Z kolei wskaźniki ekologiczne dotyczą zmniejszania oddziaływania na środowisko naturalne, z którym rolnictwo jest ściśle związane: mniej odpadów, mniejsza skala produkcji (produkcja ekstensywna), a także zaangażowanie producentów rolnych w różne projekty na rzecz ochrony środowiska (programy rolnośrodowiskowe, produkcja ekologiczna, ochrona bioróżnorodności). Podstawą funkcjonowania takiego systemu są małe, rodzinne gospodarstwa rolne, które dzięki możliwości przetwarzania żywności na małą skalę mają możliwość sprzedaży produktów i podnoszenia swoich dochodów. Czynniki wpływające na łańcuch dostaw przedstawiono na rysunku 3, na którym zamieszczono klasyczny oraz skrócony łańcuch żywnościowy. 


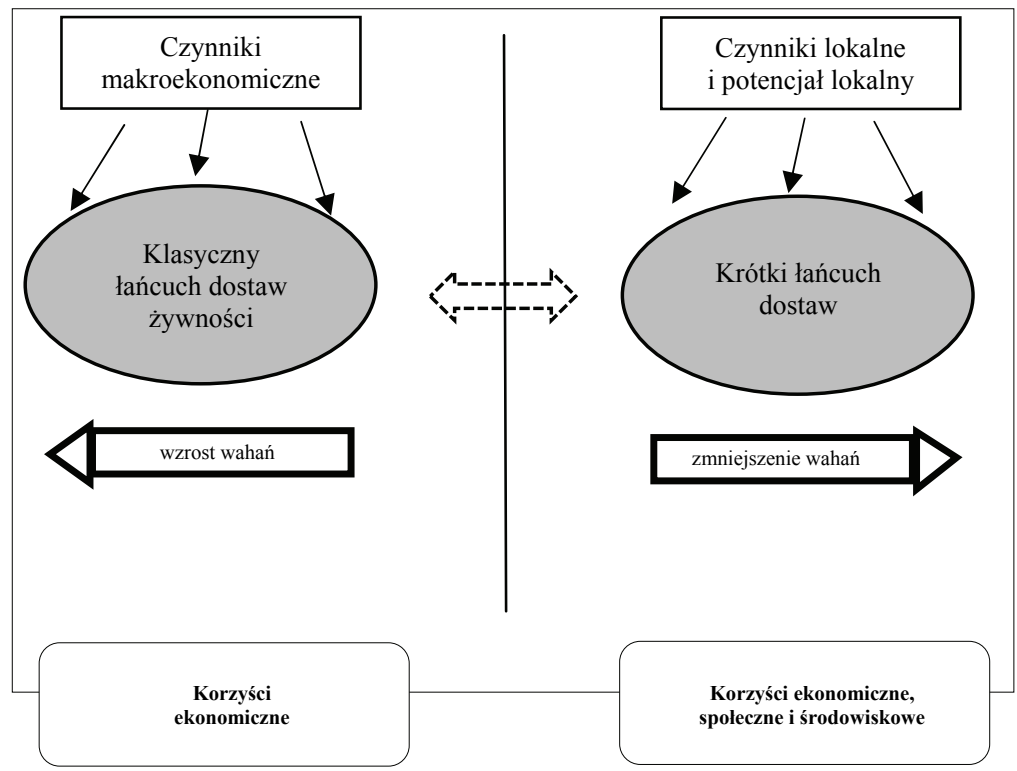

Rys. 3. Czynniki i korzyści zarządzania łańcuchem żywnościowym

Fig. 3. Factors and benefits of food chain management

Źródło: opracowanie własne.

Zmniejszenie ogniw łańcucha jest równoznaczne ze zmniejszeniem potencjalnych zagrożeń, które mogą się pojawić w tradycyjnym modelu łańcucha dostaw dowolnego produktu. Efektem jest zmniejszenie wahań, a więc zminimalizowanie wpływu negatywnych implikacji zewnętrznych i reperkusji takich efektów jak np. efekt Forrestera. Klasyczny łańcuch żywnościowy i wdrażane w nim innowacje, mają charakter zarówno produktowy, jak i procesowy. Ich głównym celem jest poprawa sprawności i skuteczności przepływów dostaw, co przynosi uczestnikom łańcucha wymierne korzyści. Korzyści społeczne odnoszą się do dostarczania społeczeństwu zdrowszej żywności, głównie o zasięgu lokalnym i regionalnym, oraz możliwości identyfikacji z danym regionem (poczucie przynależności). Korzyści środowiskowe to przede wszystkim ograniczenie odpadów i zmniejszenie negatywnego wpływu na środowisko. Dzięki zintegrowanemu działaniu krótkich łańcuchów dostaw żywności możliwa jest także ochrona wartości przyrodniczych, kulturowych i krajobrazowych danego regionu.

\section{Podsumowanie}

Wielu naukowców, cytowanych w niniejszej pracy, podkreśla wpływ łańcucha żywnościowego na sytuację ekonomiczna, społeczną a także ekologiczną społeczeństwa, kraju czy danego regionu. A. Czyżewski (2001), a także inni Autorzy wskazują na konieczność badania relacji procesów występujących w łańcuchu żywnościowym z tymi trzema obszarami życia społecznego. Aby poprawić efektywność łańcucha żywnościowego, a także usprawnić jego procesy wprowadzane są innowacyjne rozwiązania 
(np. just-in-time, Kanban, procesy zarządzania jakością, itd.). W niniejszej pracy dokonano analizy procesów zarządzania łańcuchem żywnościowym, z uwzględnieniem koncepcji krótkich łańcuchów dostaw, na przykładzie funkcjonującej idei Produktu Lokalnego z Małopolski. Celem pracy była próba odpowiedzi na pytanie jakie są korzyści krótkich łańcuchów dostaw oraz jaki jest ich zasięg. Bez wątpienia na koncepcji krótkich łańcuchów dostaw zyskują producenci rolni (zwiększenie potencjału negocjacyjnego, większe dochody, zmniejszenie kosztów produkcji, mniejsza konkurencja, wzajemne wsparcie, wymiana wiedzy i informacji, innowacje technologiczne, innowacje produktowe, nowe podejście do logistyki), a także konsumenci (lepsza jakość produktów, produkty mniej przetworzone, zdrowa żywność, produkty ekologiczne, produkty unikatowe - lokalne, regionalne, tradycyjne). Korzyści odnoszą się także do danego regionu (tworzenie lokalnej infrastruktury przetwórstwa, cross-learning między zainteresowanymi stronami (rolnikprzetwórca-lokalne instytucje-konsument).

Współcześnie występuje silna asymetria siły w łańcuchu żywnościowym. Z jednej strony występują duże korporacje produkujące i przetwarzające żywność na szeroką skalę, podczas gdy po drugiej stronie mamy rozdrobnione rolnictwo, zwłaszcza w Europie (Europejski Model Rolnictwa). Innowacyjne koncepcje modyfikacji łańcucha żywnościowego w kierunku ograniczania jego ogniw, mogą spowodować wzmocnienie pozycji rolnika w łańcuchu żywnościowych. Procesy integracji działań rolników oraz skracanie łańcucha żywnościowego skutkują wzmocnieniem pozycji producentów rolnych na rynku, a także w samym łańcuchu żywnościowym (Renting, Marsden, Banks, 2003). K. Brodzińska (2014) jako przykład wykorzystania koncepcji krótkich łańcuchów dostaw wskazuje rynki ekologiczne, zwłaszcza te o zasięgu lokalnym. Produkcja ekologiczna, która $\mathrm{z}$ jednej strony przyczynia się do poprawy stanu środowiska przyrodniczego oraz dostarcza lokalnie produkowaną i żywność, stanowi potencjał w zakresie kreowania nowych rozwiązań w kierunku poprawy efektywności łańcucha i zwiększania jego konkurencyjności (Mickiewicz i in. 2015). Koncepcja krótkich łańcuchów dostaw i sprzedaży bezpośredniej powinna być szczególnie promowana w programach rozwoju obszarów wiejskich (Kneafasy i in., 2013).

Podsumowując należy podkreślić, iż konieczne jest całościowe podejście do przedstawionego $\mathrm{w}$ niniejszym artykule zagadnienia. Założenia wynikające $\mathrm{z}$ chęci wyeliminowania niekorzystnych zjawisk występujących $w$ tradycyjnym łańcuchu żywnościowym wskazują, że jednym z korzystnych rozwiązań może być skrócenie łańcuchów dostaw i jej wykorzystywanie w drodze „od rolnika do stotu”. Przy eliminowaniu niekorzystnego efektu Forrestera jednym ze sposobów jego zminimalizowania jest zmniejszenie liczby ogniw współuczestniczących $\mathrm{w}$ procesie przepływu, gdyż każde $\mathrm{z}$ nich wzmacnia to negatywne zjawisko pojawiające się $\mathrm{w}$ klasycznym łańcuchu dostaw. Mniej ogniw w łańcuchu to mniej możliwości popełnienia błędów w procesach zarządzania oraz mniej okazji do wystapienia strat. Koncepcja ta uwzględnia teorię ograniczeń (Theory of Constraints), gdyż powoduje wzmocnienie lub wyeliminowanie najsłabszych ogniw w łańcuchu. W całym łańcuchu optymalizacja wymaga spojrzenia szerszego niż tylko przez pryzmat działań wycinkowych i doraźnych, konieczne jest zatem podejście systemowe do tego zagadnienia.

We wskazanym przykładzie praktycznym daje się wyraźnie zauważyć, że skrócenie łańcucha dostaw znacząco wpływa na funkcjonowanie jego ogniw. Szczególnie widoczne staje się to w obszarze dystrybucji. Dywersyfikacja kanałów dystrybucji mogłaby wpływać na powiększanie efektu Forrestera, jednak samo skrócenie łańcucha i wyeliminowanie 


\section{J. Nowakowska-Grunt, B. Kietbasa}

ogniw pośredniczących $\mathrm{w}$ istocie wpływa na jego obniżenie. W konsekwencji uzyskuje się wzrost konkurencyjności łańcucha dostaw. Należy pamiętać, iż koncepcja krótkich łańcuchów dostaw żywności ma wymiar lokalny i skupia się na wykorzystaniu mocnych stron danego regionu, oraz na minimalizowaniu słabych stron małych gospodarstw rolnych i drobnych przedsiębiorców. Jest to szansa na podniesienie konkurencyjności nie tylko tych podmiotów, ale także regionów, poprzez wykorzystanie ich społecznego i przyrodniczego potencjału.

\section{Literatura}

Baran, J., Maciejczak, M., Pietrzak, M., Rokicki, T., Wicki, L. (2008). Logistyka: wybrane zagadnienia. Warszawa: Wydawnictwo SGGW.

Bezat-Jarzębowska, A., Jarzębowski, S. (2014). Zarządzanie łańcuchem dostaw. W: B. Klepacki, L. Wicki (red.) Systemy logistyczne w funkcjonowaniu przedsiębiorstw rolno-spożywczych (s. 136-160). Warszawa: SGGW.

Brodzińska, K. (2014). Rolnictwo ekologiczne - tendencje i kierunki zmian. ZN SGGW Problemy Rolnictwa Światowego, 14(3), 27-36.

Canfora, I. (2016). Is the Short Food Supply Chain an Efficient Solution for Sustainability in Food Market? Agriculture and Agricultural Science Procedia, 8, 402-407.

Ciesielski, M. (2009). Instrumenty zarządzania łańcuchami dostaw. Warszawa: PWE.

Czyżewski, A. (2001). Współczesne problemy agrobiznesu w Polsce. Poznań: Wydawnictwo AE.

Firlej, K. (2008). Rozwój przemysłu rolno-spożywczego w sektorze agrobiznesu i jego determinanty. Kraków: Uniwersytet Ekonomiczny.

Galli, F., Brunori, G. (eds.). (2013). Short Food Supply Chains as drivers of sustainable development. Evidence Document. Document developed in the framework of the FP7 project FOODLINKS (GA No.265287). Laboratorio di studi rurali Sismondi.

Gołębiewski, J. (2007). Systemy marketingowe produktów żywnościowych: aspekty teoretyczne. W: J. Gołębiewski (red.) Systemy marketingowe produktów roślinnych: aspekty organizacyjne i instytucjonalne (s. 9-22). Warszawa: SGGW.

Gołębiewski, J. (2010). Efektywność systemów marketingowych w gospodarce żywnościowej. Warszawa: SGGW.

Grupa fokusowa EIPAGRI Innowacyjne Zarządzanie Krótkim Łańcuchem Dostaw Żywności, RAPORT KOŃCOWY 30 listopada 2015. Pobrano 17 stycznia 2017 z: $\quad$ http://produktlokalny.pl/wpcontent/uploads/2015/02/30_PL-EIP-AGRI-SFC-REPORT.pdf.

Hugos, M. (2003). Essentials of Supply Chain Management. New Jersey: John Wiley\&Sons, Hoboken.

Jarzęowski, S., Klepacki, B. (2013) Łańcuchy dostaw w gospodarce żywnościowej. ZN SGGW Ekonomika i Organizacja Gospodarki Żywnościowej, 103, 107-117.

Juchniewicz, M., Grzybowska, B. (2010). Diagnoza innowacyjności mikroprzedsiębiorstw w Polsce: omówienie wyników badań empirycznych. Warszawa: PAPR.

Juchniewicz, M. (2015). Innowacje w logistyce łańcucha dostaw żywności. ZN Uniwersytetu Szczecińskiego Problemy Zarzadzania, Finansów i Marketingu, 41 (2)/875, 473-482, DOI: 10.18276/pzfm.2015.41/2-38.

Kalinowski, S., Zielińska-Chmielewska, A. (2014). Strategie rozwoju przedsiębiorstw przetwórstwa owocowowarzywnego z Wielkopolski. Roczniki Naukowe Stowarzyszenia Ekonomistów Rolnictwa i Agrobiznesu, 16(6), 202-207.

Kawecka, A., Gębarowski, M. (2015). Krótkie łańcuchy dostaw żywności - korzyści dla konsumentów i producentów żywności. Journal of Agribusiness and Rural Development, 3(37), 1-7. DOI: $10.17306 /$ JARD.2015.47

Kozera, M. (2007). Struktura łańcucha żywnościowego oraz zmiany relacji producent-konsument $\mathrm{w}$ Polsce i krajach UE. ZN SGGW Problemy Rolnictwa Światowego, 2(17)/2, 240-246.

Klepacki, B. (2008). Rozwój logistyki jako czynnik wzrostu konkurencyjności przedsiębiorstw agrobiznesu. Roczniki Naukowe Stowarzyszenia Ekonomistów Rolnictwa i Agrobiznesu, 10(3), 307-311.

Klepacki, B. (2011). Agrologistyka: nowe wyzwania dla teorii i praktyki. Logistyka, 3, 12-13.

Klepacki, B. (2016). Miejsce i znaczenie logistyki w agrobiznesie. Ekonomika i Organizacja Logistyki, 1(1), 7-18. 
Knapik, W. (2016). Innowacje produktowe i procesowe w aspekcie zrównoważenia ekonomiczno-społecznego uwzględniającego bezpieczeństwo żywności - studium przypadku - propozycja nowych rozwiązań. ZN SGGW Problemy Rolnictwa Światowego, 16(3), 181-191.

Kneafasy, M., Venn, L., Schmutz, U., Balázs, B., Trenchard, L., Eyden-Wood, T., Bos, E., Sutton, G., Blackett, M. (2013). Short Food Supply Chains and Local Food Systems in the EU. A State of Play of their SocioEconomic Characteristics. (red.) F. Santini, S. Gomez y Paloma. European Commission Joint Research Centre Institute for Prospective Technological Studies.

Lee, H., Padmanabhan, P., Whang, S. (1997). Information Distortion in a Supply Chain: The Bullwhip Effect. Management Science 43, 546-558.

Local Food and Short Supply Chains (2017). http://enrd.ec.europa.eu/enrd-static/themes/local-food-and-shortsupply-chains/en/local-food-and-short-supply-chains en.html (data dostępu 13.03.2017).

Małysz, J. (1998). Łańcuch żywnościowy. W: R. Woś (- red.) Encyklopedia Agrobiznesu. Warszawa: Fundacja Innowacja.

Mickiewicz, A., Mickiewicz, B., Prus, P., Wawrzyniak, B. M. (2015). Miejsce i rola jednostek certyfikujących oraz inspektorów w systemie rolnictwa ekologicznego w Polsce. Zagadnienia Doradztwa Rolniczego 3, 42 61.

Myerson, J.M. (2007). RFID in the Supply Chain. A Guide to Selection and Implementation. New York: Auerbach Publications, Taylor\&Francis Group.

Nowakowska-Grunt, J., Parzonko, A.J., Kiełbasa, B. (2016). Determinants of Managing Networks of Organizations in Rural Areas. Częstochowa: Wydział Zarządzania.

Parlińska, M. (2015). Rodzinne gospodarstwa rolne podstawą rozwoju rolnictwa i samoorganizacji społecznych na wsi. W: A. Chlebicka (red.) Ekonomiczne mechanizmy wspierania i ochrony rolnictwa rodzinnego w Polsce i innych państwach Unii Europejskiej. Warszawa: MRiRW, FAPA. Pobrane 22 kwiecień 2016 z: http://ksow.pl/uploads/tx_library/files/Ekonomiczne_mechanizmy_wspierania_i_ochrony_rolnictwa_rodzim ego_2015.pdf

Pluta-Zaremba, A. (2002). Efekt byczego bicza w łańcuchu dostaw. Gospodarka Materiałowa i Logistyka, 5, 11 16.

Pudełkiewicz, E. (2011). Refleksje wokół koncepcji marketingu w agrobiznesie. Polityki Europejskiej, Finanse i Marketing, 5(54), 115-130.

Produkt Lokalny z Małopolski (2017). http://produktlokalny.pl/ (data dostępu 12.02.2017)

Prus, P. (2008). Rola grup producenckich w podnoszeniu konkurencyjności gospodarstw rolniczych. Roczniki Naukowe Stowarzyszenia Ekonomistów Rolnictwa i Agrobiznesu, 10(3), 456-461.

Renting, H., Marsden, T.K., Banks, J. (2003). Understanding Alternative Food Networks: Exploring the Role of Short Food Supply Chains in Rural Development. Environment and Planning A., 35(3), 393-411.

Szymanowski, W. (2008). Zarządzanie łańcuchami dostaw żywności w Polsce: kierunki zmian. Warszawa: Difin.

The Agricultural European Innovation Partnership, www.eip-agri.eu (data dostępu 22.02.2017)

Tul-Krzyszczuk, A., Krajewski, K. (2014). Innowacje organizacyjne w handlu produktami żywnościowymi doświadczenia, specyfika. Roczniki Naukowe Stowarzyszenia Ekonomistów Rolnictwa i Agrobiznesu, 16(2), 294-298.

Witkowski, J. (2010). Zarządzanie łańcuchem dostaw: koncepcje, procedury, doświadczenia. Warszawa: PWE.

Van der Vorst, J. (2000). Effective food supply chains. Generating, modelling and evaluating supply chain scenarios. Uniwersytet Wageningen. 